Archived version from NCDOCKS Institutional Repository http://libres.uncg.edu/ir/asu/

\title{
Appalachỉan
}

B O O NE, NORTH CAROLINA

\section{Non-State Ambassadors: Ngos' Contribution To America's Public Diplomacy}

\author{
By: Olga Zatepillina-Monacell
}

\begin{abstract}
This qualitative research paper explores how American non-state actors de facto contribute to US public diplomacy efforts while preserving their freedom of disagreement with government policies. In-depth interviews with 14 representatives of 12 US nonprofit nongovernmental organisations (NGOs) were conducted to look at their institutional and individual experiences of communicating with various foreign publics. NGOs' good standing in host countries depends on their ability to build relationships with and empower their local partners. The government could capitalise on NGOs' successes by highlighting their achievements in providing development assistance, as well as their autonomy, diversity and right to dissent. The study provides a baseline for further research on the unrealised capabilities of US civil society in strengthening America's reputation worldwide.
\end{abstract}

Zatepilina-Monacell, O. (2009). "Non-State Ambassadors: Ngos' Contribution To America's Public Diplomacy." Place Branding and Public Diplomacy, 5(2), 156-168 (May 2009). (ISSN: 1751-8059). Version of record available from www.proquest.com 


\section{INTRODUCTION}

As the controversial US-led occupation of Iraq continued alienating governments and individuals around the world, the diplomatic, think-tank and media communities have been debating over what changes in foreign policies and in communication strategies might improve America's reputation abroad; scholars from a variety of disciplines have joined the debate as well (Snow, 2003, 2006; Nye, 2004; Anholt, 2005; Fullerton and Kendrick, 2006; Kohut and Stokes, 2006; Fullerton et al , 2007; Pilon, 2007; Ross, 2007; Cowan and Cull, 2008).

This paper explores the role of non-state actors - such as nonprofit nongovernmental organisations (NGOs) - in the United States' public diplomacy. The study posits that some US NGOs have been, implicitly or explicitly, engaged in public diplomacy for some time. Specifically, it looks at NGOs' efforts to build relationships with foreign publics and manage organisational reputation overseas to suggest that, if supported by a formally recognised framework integrating state and not-state public diplomacy, NGOs feel that they conceivably could do much more to advance America's standing worldwide.

\section{LITERATURE REVIEW}

\section{Public diplomacy definitions}

Public diplomacy is a nation-state's direct or non-state-actor-mediated communication with the people of other countries to (1) shape a favourable foreign public opinion about the nation (Malone, 1988; Manheim, 1994; Osgood, 2006; Pigman and Deos, 2008); (2) gain a better understanding among foreign publics (Tuch, 1990; Cowan and Arsenault, 2008); and (3) build a positive image/brand/reputation for the country overseas (Kunczik, 1997; Nye, 2004; Anholt, 2005; Arndt, 2005). But ultimately, public diplomacy seeks to (4) influence the behaviour and policies of foreign governments by influencing the attitudes and opinions of foreign citizens (Malone, 1988; Tuch, 1990; Manheim, 1994).

Some believe that public diplomacy is a government's public relations, although, on occasion, scholars and practitioners of the two disciplines disassociate from one another (Signitzer and Coombs, 1992; Grunig, 1993; Manheim, 1994; Pigman and Deos, 2008). Others regard public diplomacy as international public relations practiced not only by governments, but also by any type of organisation - public or private, for profit or nonprofit (Grunig, 1993; Kunczik, 1997). Notwithstanding the preferred terminology, public diplomacy and public relations often pursue the same objective - that is, to affect public opinion for the benefit of their client or organisation (Malone, 1988; Signitzer and Coombs, 1992; Manheim, 1994). 
Alas, the enduring use of the term public relations interchangeably with propaganda and publicity by certain journalists, government practitioners or scholars disaffects those who are not familiar with the latest research in the field. Therefore, public relations' role in public diplomacy efforts hinges on its ability to go beyond propaganda and publicity (Kruckeberg and Vujnovic, 2005). With this understanding in mind, some recent studies have proposed applying the theories of excellence (Yun, 2006, 2008), reputation management (Yang and Grunig, 2005; Wang, 2006) and country branding (Anholt, 2005) in the public diplomacy context.

\section{Relationship-building and reputation theories in public diplomacy}

The public relations and corporate communications theories that guided this research are briefly reviewed here through the prism of public diplomacy. The two-way symmetrical model of communication (Grunig and Grunig, 1992) has been frequently brought up in discussions on what has gone wrong with US public diplomacy. Grunig and Grunig (1992) established that most successful organisations not only listen to what their publics have to say (that is, two-way communication), but also strategically place as much emphasis on their publics' interests as on their own (that is, symmetric communication).

The two-way symmetrical model inevitably leads organisations to engage in relationship-building (Grunig and Repper, 1992; Bruning and Galloway, 2003). Several theories focus on the importance of relationship-building in organisational communication (Ledingham and Bruning, 2000; Broom et al , 2000; Hung, 2007). The idea is that organisational success or failure pivots on strategic relationships with stakeholders and publics. 'Organization-public relationships involve an ongoing interchange of needs, expectations, and fulfillment,' maintained Ledingham (2003, p. 188). Public relations programmes that target the public at large communicate with no one of importance to the organisation (Grunig and Repper, 1992, p. 118), whereas those aiming to build mutually beneficial relationships result in such outcomes as trust, satisfaction and commitment (Hon and Grunig, 1999; Grunig and Huang, 2000).

In the same way, public diplomacy programmes should shift from communicating with the entire world to cultivating relationships with those foreign publics that have a stake in the success of this country and its values. Nye made a case for relationship-building in public diplomacy: 'The third dimension of public diplomacy is the development of lasting relationships with key individuals over many years through scholarships, exchanges, training, seminars, conferences, and access to media channels' (2004, p. 109). Cowan and Arsenault argued that 'an effort could be made to expand citizen diplomacy beyond dialogue and exchanges to joint projects and collaborative endeavors' $(2008$, p. 26).

Although relationship-building is a resource- and time-intensive effort affecting fairly small numbers of people (Hutton et al , 2001), organisation-public 
relationships impact organisational reputation greatly (Fombrun, 1996; Yang and Grunig, 2005). Scholars define reputation as 'cognitive representations of organizations in the minds of publics' (Yang and Grunig, 2005, p. 321) and 'overall evaluation of a company over time' (Gotsi and Wilson, 2001, p. 29). Stakeholders and publics base their perceptions on their direct experiences with the organisation, and on communication and symbols that compare the organisation's action with those of its rivals (Gotsi and Wilson, 2001).

Reputation in world politics matters as much as it does in the corporate world, argued Nye (2004). Governments and politicians' credibility is a power resource that countries rely upon in their relations with the world (Kunczik, 1997; Nye, 2004; Wang, 2006). In a public diplomacy context, a country's reputation is determined by three key factors: (1) its relationships with foreign publics, (2) foreign publics' direct experiences with the country, and (3) the communications and symbols contrasting its actions to those of other countries.

\section{NGOs and public diplomacy}

As the study of public diplomacy has begun embracing the relationship and reputation theories, those concerned with the status quo in the practice of public diplomacy have recognised the importance of engaging various domestic actors other than the government itself - in the efforts to improve the United States' standing overseas (Council on Foreign Relations, 2003; US General Accounting Office, 4 September 2003; Nye, 2004; Arndt, 2005; Lord, 2006; Pigman and Deos, 2008; Snow Jr., 2008). In 2007, Secretary of State Condoleezza Rice launched a 'transformational diplomacy' initiative that called upon the private sector to take part in US public diplomacy's endeavours around the world (US Department of State, 9 January 2007).

Snow Jr. (2008) argued that among various private organisations involved in what used to be the government's domain, nonprofit NGOs stand out because, unlike others, they recognise the role they play in public diplomacy. Nonprofits and in particular development NGOs - are gaining power in world affairs (Taylor, 1984; Simmons, 1998; Bennett, 2000; Ripinsky and Van den Bossche, 2007). Atack (1999) described development NGOs as actively attempting to influence governments' and multilateral institutions' development policies. Edwards characterised the global engagement of development NGOs as 'cost-effective public relations' $(2000$, p. 11) for both nation-states and international organisations.

Referring to NGOs' political interests and agendas, however, Simmons (1998) argued that 'they have the potential to do as much harm as good' (p. 83). Development NGOs are more likely than any other types of NGOs to be scrutinised for their dependence on government funds (Salamon, 1994; Atack, 1999; Josselin and Wallace, 2001). Indeed, many US-based NGOs that receive government funds have often been criticised by those who oppose US foreign 
policies (Guilhot, 2005; Barker, 2008). On the other hand, NGOs' contributions to strengthening democratic processes in Eastern Europe and elsewhere have also been documented (Pilon, 2007; Richmond, 2008).

As some had succeeded and others had failed in their democracy-building endeavours, most NGOs appear to have recognised that there are alternatives to the US democratic model (Lord, 2006). This recognition is yet to find reflection in US foreign policies and public diplomacy programmes. At the same time, US development and humanitarian aid, as well as support for free media, education and human rights, are tools of strategic influence that enhance public diplomacy (Lord, 2006). Unfortunately, argued Lord, little is being done to publicise or highlight the processes of democratisation and development of market economies.

The reviewed literature led the author to posit that (1) non-state actors' involvement is essential for public diplomacy; (2) non-state actors' experiences in building institutional relationships and managing organisational reputations overseas add value to the reputation of their country of origin; and (3) the potential of NGO public diplomacy remains unrealised. The following research questions were addressed in this study:

$\mathbf{R} \mathbf{Q}_{1}$

What factors affect NGOs' reputations overseas?

$\mathbf{R Q}_{2}$

What lessons have US nonprofit NGOs learned while interacting with various foreign publics?

$\mathbf{R Q}_{3}$

What else could be done by US non-state actors - and NGOs in particular - to contribute to US public diplomacy and improve America's reputation abroad?

\section{METHOD}

In-depth interviews were conducted with 14 current and former staff members of 12501 (c)(3) nonprofit NGOs operating in the areas of conflict resolution, democracy-building, education and media. A purposive, snowballing sampling was used to select individuals mainly from the Washington DC-based NGO community. The rationale for choosing participants from this population included: (1) the represented development NGOs identify themselves as US organisations that have a global presence and direct contacts with a multitude of foreign 
publics; (2) the represented nonprofit media organisations work in tandem with foreign producers and journalists both in the United States and abroad; and (3) although growing rapidly, these specific areas within the US international development industry (that is, democratisation, human rights, education, conflict resolution and media) are still dominated by a relatively small number of NGOs.

The sample included individuals who either are or had been employed by one or more of the following NGOs: American Abroad Media (AAM), American Councils for International Education (ACTR/ACCELS), Drug Abuse Resistance Education (D.A.R.E.), the Foundation for International Understanding (FIU)/Center for the Study of the Presidency, International Foundation for Electoral Systems (IFES), the International Republican Institute (IRI), Layalina Productions, Inc., the National Democratic Institute for International Affairs (NDI), the Research Triangle Institute (RTI), State University of New York's Center for International Development (SUNY-CID) and the US Institute of Peace (USIP). ${ }^{1}$ The NGOs differ in the type of funding they receive: (a) one donor, that is, one US government agency (USIP); (b) multiple donors but mainly US government agencies (IFES, IRI, NDI, SUNY/CID and RTI), (c) mixed government-private (ACTR/ACCELS and D.A.R.E.); and (d) private only (AAM and Layalina Productions, Inc.).

To be included in the sample, individuals had to have experience either working overseas or managing a programme focusing on a foreign region/country. All names were changed to pseudonyms. The sample included eight male and six female participants. Most interviewees hold advanced degrees (seven Masters' and three doctoral) in communication, international relations, political science and public administration. Currently, 10 interviewees are employed by these NGOs; two work in the private sector and one in government; and one is at graduate school. At one time, six interviewees worked for another of the 12 NGOs and one was employed by three of these 12 NGOs. Additionally, at least five of the interviewees were formerly employed by a government institution (for example, US Department of State) where their jobs focused on international development.

The in-person interviews with 10 participants were held during the week of 9 March 2008 in Washington DC. As the remaining four participants were posted overseas at the time, they were interviewed the following week, over Skype, an Internet phone service with recording capabilities. The 45-90 min semi-structured interviews consisted of five open-ended questions.

Although the interviewees used examples of their NGOs that are both comparable and different, inevitably each participant shared her/his personal experiences and opinions, which may or may not be shared by the respective NGO. Almost everyone emphasised that they do not think of themselves as experts in the field, and the author assured them that she was not looking for an 'expert opinion' - rather, for alternative perspectives. 
Throughout this study - from formulating its research questions to identifying cases, and from collecting to interpreting the data - the researcher's personal and professional experience was used to better understand opinions shared by the participants. This author's interest in and knowledge of the non-state sector and public diplomacy stem from several years of working overseas with nongovernmental development organisations, including one of these 12 NGOs.

\section{RESULTS AND DISCUSSION}

Two broad contexts emerged from the interviews: (1) the actual practice of nonstate public diplomacy and (2) the unrealised capabilities of non-state public diplomacy. Several themes that arose from within each of the contexts were clustered into four subjects: (1) cooperation with, trust in and empowerment of foreign partners; (2) mutual respect as a basis for both individual and institutional relationship-building; (3) credibility of non-state actors; and (4) dissent and diversity as powerful messages. In addition, as a recurrent theme, state public diplomacy and NGO public diplomacy were contrasted throughout most interviews.

\section{Cooperation, trust and empowerment}

Interviewees with both international development and media backgrounds emphasised the importance of cooperation, trust and empowerment. Several participants argued that most successful development NGOs - as recognised by both their donors and recipients - involve their foreign counterparts in the design, implementation and evaluation of their programmes. And some of the best broadcasts - as supported by audience research overseas - are those produced in conjunction with NGOs' foreign media partners.

Most participants see development NGOs' purpose as sharing knowledge with their foreign publics (for example, how to solve a conflict, how to campaign, how to lobby, how to produce a TV show and so on) rather than as pushing an issue or an outcome (for example, convert them to a religion, get someone we want elected, broadcast our content and so on). When NGOs impose development programmes without consulting local partners, the programmes inevitably fail. Other programmes fail because NGOs do not trust their local partners.

Meghan gave an example of a programme in Iraq where IRI initiated youth centres in Baghdad: 'We assumed we can't show the budget to the Iraqi counterparts. We wrote the project, came up with activities and made them come together. But there was no natural formation'. Having learned from that mistake, Meghan's team took a different approach in the south of Iraq and in Kurdistan: 'We were more open about the budget. We invited people to meet and see how 
they can work together. Then we helped them develop budget so it wasn't a secret. The project was a shared thing, more authentic and they all signed up'.

Both Alfred of AAM and Cari of Layalina emphasised that their TV and radio programmes are co-productions with foreign journalists or producers. 'It's the only effective way to reach local audiences', argued Nathan of FIU. Foreign partners have firsthand knowledge of specific media markets, and, most of all, of specific audiences, cultures and languages. Alfred explained,

Our programs are collaborative in nature. You have to listen, take your counterparts seriously, understand what their worldview is, their assumptions are, and then you have to try to explain which part you think is fair and accurate and which parts are not (...). There's always a potential for misperception and it's certainly true between two different cultures. The challenge is the level of trust (...).

Most participants agreed that no matter how much money NGOs spend, they gain respect only if and when they enable local partners to take control of their lives. Ashley of USIP argued,

Sharing process is what represents America's spirit, but if you try to impose an outcome you no longer represent America (...). People need help with the processes; they don't need help with making their decisions. They want to make their own decisions and have the outcome they want. They want to be involved, they want to have a say - that is they want their own democracy.

Some participants criticised their fellow members of the NGO community who adopt a neo-colonial attitude toward their hosts. Such an attitude not only enhances the 'ugly American' stereotype, but is also detrimental to their organisational reputation. On the other hand, Ryan believes these are occasional rotten apples, whereas numerous NGOs contribute to creating a positive image of the United States:

The good NGOs can do a lot of good work in this arena without even trying and, in fact, many are already doing it: working in an area long term, keeping the expat staff small, encouraging expats to work themselves out of a job and replace them with locals whenever appropriate, making sure expat staff live on the local economy and not on the diplomatic economy, making sure expat staff speak the language. I know so many instances of American individuals making huge impressions when those conditions are in place. It only takes one to change the opinion of a whole community.

\section{Relationship-building}

Almost all interviewees pointed out that their organisations' success abroad hinges on their expatriate and local employees' abilities to build relationships with 
host organisations and individuals. Participants distinguished several levels of relationships between NGOs and foreign publics: formal, informal and friendships. They also differentiated relationships by the counterpart: local staff members, members of local partner organisations and foreign elites. Many interviewees emphasised that regardless of the level or type of a relationship, it has to be based on mutual respect.

Both Evan and Noah used their experiences in East Africa and the former Soviet Union, respectively, to compare the relationships NGOs and diplomatic missions maintain in host countries. Unlike diplomats, who 'are always representing the United States, we have this opportunity to go beyond the country we represent and develop friendships', argued Evan of NDI and formerly of SUNY-CID. 'I was able to develop informal relations with our partners. As a result, my working relations with them were greatly enhanced and information flow was better', said Noah of RTI and formerly of NDI. Noah, who is currently in Iraq, believes his NGO has not been successful in implementing its programmes in that country because the precarious security situation prevents its staff from establishing informal relationships with organisations and individuals: 'The fact that we cannot engage socially with our partners seriously hampers our efforts'.

Although expatriates maintain working relationships on behalf of their NGOs, the quality of those relationships, and, ultimately, the reputation of their NGOs, are based on individuals' abilities to build personal trust and respect with foreign publics. Furthermore, not only expatriate individuals, but also NGOs' local staff members impact NGOs' institutional relationships. In many cases, perceptions about an organisation are determined by who its local employees are. Erin, formerly of IRI, pointed out that

The individuals working on the ground, through their personal relationships with our local partners, projected a certain impression of us as an organization and of US citizens in general. Certain stereotypes about America may or may not have been broken depending on who these individuals were and how their relations with counterparts developed.

Many NGOs maintain contacts with gatekeepers in host countries. However, several participants pointed out that they are more successful at building relationships with foreign civil societies than with foreign governments, although some organisations enjoy a close rapport with both. In the case of IFES, IRI and $\mathrm{NDI}$, for example, often the political parties these NGOs work with win seats in national parliaments, thus making these organisations welcomed in host countries' government circles. Needless to say, the opposite happens as well: sometimes the ruling party in a host country marginalises international NGOs for working with the opposition. Several participants observed that US diplomats frequently consult with the NGOs that have access to foreign elites - both state and non-state; however, occasionally, Foreign Service Officers (FSOs) take a somewhat patronising stance toward those NGOs. In these cases, NGOs tend to 
push back and lose interest in cooperating with their US government counterparts.

Some participants believe their organisations are more flexible than the government in reaching out to various opposition or extremist groups in host countries. 'Sometimes, we have hotheads in the audience, which is good because when you talk about conflict resolution you don't want just to preach to the choir', argued Ashley. More often, however, USIP works with people from 'the choir and from the outskirts of the choir' who can then reach out to the radicals, and, hopefully, promote the idea of conflict management.

\section{Perceived credibility}

By virtue of being independent from the government, NGOs enjoy more credibility among foreign publics, maintained many participants. According to Alfred and Cari, most audiences overseas are suspicious of governments, and, therefore, US government-owned media outlets such as Alhurra or Radio Sawa are largely unpopular, whereas productions by AAM and Layalina are better received. Currently, neither AAM nor Layalina receive government funding. Although this might change in the future, for now Alfred and Cari believe that their private funding serves as yet another proof of independence:

We're seen as an example of something emanating from the American Society (...). The fact that we're an independent NGO is important to the channels that we are in partnership with because they feel we're in a position to say whatever we want about a particular administration or a particular government. (Alfred, AAM)

In addition, unlike their government-owned counterparts, AAM and Layalina are not perceived as propagandist outlets, because they provide more balanced programming, argued Alfred and Cari. Even though they often present the US government's perspective and feature US government representatives, they strive to always cover the opposing side as well.

Likewise, international development NGOs are often perceived as more credible because they 'work directly with the people, and are one step removed from the government' (Erin, formerly of IRI). NGOs' latitude of movement and freedom of speech within host countries were mentioned by many as prerequisites to being seen as trustworthy by local publics:

I was at a distinct advantage over US FSOs because I was able to be much closer to the ground (...). I developed relationships with both official (...) and unofficial resources (...). I was able to travel more widely, meet with people unobtrusively and not be hamstrung by official government policy. (Noah, RTI)

Sometimes, NGOs help the government in 'playing the bad guy' or 'setting the record straight', argued several participants. Doris of NDI explained, 'It's like not 
being a celebrity - you can walk on the street and no one will bother you. As nongovernment you can say certain things that a government official can't'. Some interviewees mentioned that while in host countries, NGO expatriates do not have to explain or justify government policies. Some other interviewees, on the other hand, see their role as explaining but not justifying US policy.

Several participants felt that sometimes the US Government does not recognise the value of access to and credibility with foreign publics that NGOs bring to the table. Meghan of ACTR/ACCELS remarked that FSOs 'sometimes don't know what NGOs are supposed to do and think we're a tool for government propaganda'. Citing her experience in Afghanistan, Debbie, who had worked with D.A.R.E., IFES and the Department of State, shared how some government officials used to refer to NGOs as 'loose cannon - ineffectual and not to be trusted'. Like several other interviewees, she argued that rather than dismissing NGOs, the Department of State should recognise that many NGOs have a better understanding of what is going on in host countries. American NGOs could actually share useful information and be 'a good reality check for the US government', concluded the majority of interview participants.

A few participants questioned NGOs' neutrality or perceived neutrality. Regardless of whether or not an NGO receives government funding, once in a host country it cannot completely separate itself from its government, argued some interviewees. Although many NGOs underscore their nonalignment, the development assistance they provide often affects politics in host countries. As a result, NGOs are not always seen as 'good guys' - that is, as independent and impartial - rather they are seen as actors in the power struggle. Ashley of USIP believes this is particularly relevant in conflict-ridden countries:

If NGOs train women they may affect certain status of women in the society. If they are doing economic development, they may be challenging some business interests. No matter what an NGO's engagement, in conflict-ridden and developing societies that engagement is going to change the power dynamic. Don't tell me that nobody is going to blow up the Red Cross just because the Red Cross is there to help. They are going to blow up the Red Cross because the Red Cross is doing things that affect someone's interests.

On the other hand, Ashley was sceptical of the value of having all US NGOs (in particular, religious NGOs) as part of public diplomacy efforts. Debbie, in contrast, thinks all NGOs are part of US civil society, even though some Americans might not share their values. Therefore, all NGOs operating overseas should be America's non-state ambassadors.

\section{Dissent and diversity}

Depending on individual NGOs' missions, the extent to which each organisation sees itself as a bridge between US government and foreign publics varies. Some 
NGOs, such as IFES, IRI, NDI and USIP, represent American democratic values 'by osmosis' (Doris, NDI), and, therefore, are often asked by their foreign partners to comment on US policies, or by US government officials to provide advice on foreign policy issues.

Most interviewees noted that typically their NGOs' positions are in agreement with those of US government, although occasionally they disagree on certain foreign policies. Although an NGO's analysis might be counter to US policy, argued participants, its longer-term outcome is compatible with American interests. Interviewees believe that their NGOs receive government funds to be objective - not to act as an army of yes-men.

Many participants mentioned that their NGOs not only voice their difference of opinion with the US government, but also present the relevant foreign partners with pros and cons of each option without advocating for any specific alternative. For example, in 2005, USIP disagreed with the US government on the timetable for Iraq's Constitution: USIP supported the extension, whereas the official position was to expedite the referendum. Also in Iraq, in early 2004, IFES had a dispute with the Coalition Provisional Authority (CPA) over the relationship with local civic groups in the South: IFES supported a small-grants programme for local NGOs, whereas CPA insisted on a direct hire of civic activists. A few years ago, in Kenya, SUNY-CID refused to support the US-embassy-backed antiterrorist legislation: The NGO explained to its counterparts in the Kenyan government that the US government had 'hired us to help develop democratic principles and institutions, and we can't support anti-democratic policies even if they are endorsed by our government' (Evan, NDI and formerly of SUNY-CID).

Quite a few participants strongly believe that even when American NGOs disagree with US government policies, the State Department could - and should use this disagreement as part of its public diplomacy message:

Demonstrating the ability to vocally disagree with government policy is part of being an effective public ambassador. It demonstrates the superiority of our system. (Noah, RTI) Often, the act of engaging in intelligent political debate in and of itself highlights the advantages of the US system. You don't need to sell this stuff. You just need to demonstrate it and live it and it usually sells itself. This is a huge asset that NGOs and businesses have, and an asset which US embassy officials necessarily don't have. (Ryan) NGOs represented what's important about us and about our policy - our diversity. We have all these different opinions. Not everyone is always getting what they want but everyone is protected and has the right to oppose. Sharing this with the hosts is important. Here's how we made these decisions, reached this compromise even through we're still continuing the debate in our country. The message America can share with the world is how we manage interactions among people despite the difference of opinions. (Ashley, USIP) 
Media NGOs echoed these opinions. Both AAM and Layalina incorporate diverse opinions in their programming because they believe that diversity represents this country. Cari of Layalina emphasised that his NGO does not censor its broadcast or print content: 'We're not claiming that the United States is perfect, that US policies are perfect, we just want to make sure that we're presenting an accurate picture of America'.

\section{Does the state have a monopoly on public diplomacy?}

Although the interview questions rarely if at all used the term 'public diplomacy', most interviewees provided their interpretations of the concept, and, in some instances, proposed alternative terminology. Some participants defined the concept as communicating with overseas publics, others described it as creating more accurate images of the United States, and still others conceptualised public diplomacy as building relationships with foreign partners. Only one referred to public diplomacy as government propaganda. This variance of interpretations seems to mirror the scholarly and practitioner literature's discussion on the concept of public diplomacy.

Two participants believe that public diplomacy is an exclusive government domain - that is, 'government outreach' or 'state-sponsored communications' and, thus, that only diplomats and government officials should be using the term, whereas non-state actors should refer to their interactions with foreign publics as 'citizen's diplomacy' or 'global engagement'. Most participants, however, do not think State has a monopoly on public diplomacy. Although NGO employees seldom use the term, their organisations engage in public diplomacy frequently.

Nonetheless, some interviewees recognised that their organisations do not see public diplomacy as an objective per se. Some believe that it does not need to be formulated explicitly so long as it is understood by those working abroad. Others think NGOs should make public diplomacy one of their formal priorities. Many participants from the international development industry disagree with their organisations' policies - partly enforced by government donors (for example, USAID) and partly initiated by their own management - that prevent expatriate NGO staff members from directly engaging with domestic and foreign media. Noah of RTI remarked, 'Our management's judgment was that any contact with the media was too dangerous to be handled by ordinary employees - thus sacrificing the potential to reach into the domestic and foreign societies'.

Most interviewees expressed their scepticism about certain old-fashioned public diplomacy practices. 'Even during the Cold War public diplomacy was nothing more than wishy-washy cultural exchanges and American libraries. After 9/11, we suddenly said, 'Gosh, public diplomacy is important after all,' and started employing technologically savvier versions of exactly the same thing', argued Jarrod of USIP. 
Interviewees believed that cultural and educational exchange programmes should be carried out by both state and non-state actors and become symmetrical two-way exchanges - rather than one-sided. Meghan of ACTR/ACCELS - who as a student had participated in two exchange programmes (in Albania and Italy) and had also attended a university in Belgium - argued that more American kids should participate in exchange programmes: 'Living with the family was the most eye-opening experience for me'.

Many participants were rather critical of the Broadcasting Board Governors' 'family' of media outlets, referring to their content as propaganda, and underscored the importance of two-way communication. In addition to sharing with the world America's message and the diversity of opinions in this country, media should bring foreign audiences' voices to the American people. Nathan of FIU argued, 'There's an equal value in informing Americans about abroad'.

Participants also suggested that the support American NGOs provide in various countries needs to be publicised by US embassies. If a programme is successful, people in the host country should know that it is an American NGO and a US government-funded programme. Ashley of USIP urged embassy employees to consider how to incorporate in their public diplomacy efforts messages about those US businesses and NGOs that successfully operate in the country: 'Who cares what 20 people in the embassy think when Chevron is hiring thousands of Nigerians? (...) Who cares about FSOs when Mercy Corps is training Afghan women?'

Overall, participants agreed that NGO public diplomacy is more effective yet remains overlooked by the government. 'Government public diplomacy pales in comparison with what nongovernmental entities do (...). Nongovernmental engagement is a silver lining to improving our country's reputation', remarked Nathan of FIU.

\section{CONCLUSION}

This study has looked at nonprofit NGOs' perspective on the role of non-state actors in improving America's reputation abroad. Because of this small sample size and the descriptive and exploratory nature of the study, making any inferences on the overall state of NGO public diplomacy in the United States would be speculative. Nevertheless, the opinions and ideas expressed by interviewees largely fit both the context described in the reviewed scholarly and practitioner literature and the researcher's own theoretical assumptions - that is, a broadly defined concept of public diplomacy that goes beyond state to include non-state actors, and beyond publicity to incorporate relationship- and reputationbuilding efforts. 
The study found a considerable agreement among participants on the idea that NGOs already contribute to America's public diplomacy but would do even more if their potential as public ambassadors was supported by a recognised publicprivate framework, which would integrate nongovernmental efforts in the nation's public diplomacy. Such a framework would not only ensure coordination between the government and NGOs, but also treat NGOs as an equal partner in the public diplomacy endeavours. In addition, such a framework would put emphasis on a two-way symmetrical communication with numerous constituencies around the world. And finally, the public diplomacy framework would preserve and highlight its non-state partners' autonomy from the state. Although most participants were familiar with the recent public-private initiatives (Business for Diplomatic Action, 2007; Center for Strategic and International Studies, 2007), they felt that NGOs should be encouraged to bring more to the table.

NGOs understand that their success or failure overseas depends on their institutional reputation, which in turn is determined by their relationships with foreign publics. Respect and trust for local staff and local counterparts are imperative for maintaining mutually beneficial institutional relationships in host countries. Imposing a certain American point of view is detrimental to NGOs' reputations. Sharing processes, not outcomes, makes foreign publics trust NGOs and respect their country of origin (that is, the United States).

Because of their status, NGOs enjoy the latitude in host countries and the credibility among foreign publics that US diplomats and government officials lack. On the other hand, NGOs recognise that they represent their country of origin regardless of whether they receive government funding. Therefore, many NGOs believe that their role is to explain American policies but not necessarily justify them. By voicing their disagreement with US government policies, these NGOs exemplify the debate, dissent and free speech in America, thus sending a powerful message about American values.

Through their programmes - which target various layers of foreign societies American NGOs have a great deal of interaction with and knowledge about host countries' governing and opposition political parties, civil society groups, media and opinion leaders. While the government concentrates on policy-makers and bilateral relations on the national level, NGOs focus on non-elites, grassroots and even rebels.

Moreover, while the government works on policies that will have a long-term outcome but do not always affect foreign publics directly, NGOs provide tangible assistance that makes the most difference immediately. Therefore, many NGOs believe there would be no need for propaganda if the Department of State incorporated in its messages the achievements of American NGOs operating overseas, in particular those that are US taxpayer-funded. 
Although the interviewees' opinions are not necessarily representative of the entire NGO population, and, in many cases, do not reflect the official positions of their own organisations, the data are largely consistent with the assumptions that have derived from the literature and guided the interviews: (1) the government can no longer rely on its own capabilities in communicating with foreign publics; (2) several principles of organisational communication are applicable in managing a country's reputation; and (3) NGOs are an underused factor in US public diplomacy.

The interview findings - however small the sample and however arguable the expressed opinions - contribute to expanding the agendas for both the academic and practitioner debates on NGOs' role in public diplomacy. The study puts forward some specific issues concerning NGO public diplomacy such as whether and how it should be institutionalised, what kind of NGOs should or could be included and what principles should guide the relationship between the state and NGOs in their public diplomacy cooperation.

Further research could examine the extent to which the opinions of the interviewed practitioners reflect the views on public diplomacy prevailing among their peers. It might be useful to also consider a comparison between the individual and institutional points of view within the development and media NGO populations. Additionally, looking at whether development and media NGOs' perspectives are comparable to the entire NGO community might be a fruitful research effort. Furthermore, specific case studies could identify best practices of NGO public diplomacy and make them known among both state and non-state actors interested in strengthening America's standing abroad.

\section{Footnote}

${ }^{1}$ The 12 th NGO is not identified, at the request of an interview participant. 


\section{References}

Anholt, S. (2005) Anholt nation brands index: How does the world see America. Journal of Advertising Research 45 (3): 296-304.

Arndt, R. T. (2005) The First Resort of Kings: American Cultural Diplomacy in the 20th Century. Washington DC: Potomac Books.

Atack, I. (1999) Four criteria of development NGO legitimacy. World Development 27 (5): 864-885.

Barker, M. J. (2008) Democracy or polyarchy? US-funded media developments in Afghanistan and Iraq post 9/11. Media, Culture \& Society 30 (1): 109-130.

Bennett, W. L. (2000) Introduction: Communication and civic engagement in comparative perspective. Political Communication 17 : 307-312.

Broom, G. M., Casey, S. and Ritchey, J. (2000) Concepts and Theory of Organization-Public Relationships. In: J.A. Ledingham and S.D. Bruning (eds.) Public Relations as Relationship Management: A Relational Approach to the Study and Practice of Public Relations . Mahwah, NJ: Lawrence Erlbaum Associates, pp. 3-22.

Bruning, S. D. and Galloway, T. (2003) Expanding the organization-public relationship scale: Exploring the role that structural and personal commitment play in organization-public relationships. Public Relations Review 29 (3): 309319.

Business for Diplomatic Action. (2007) America's role in the world: A business perspective on public diplomacy, http://www.businessfordiplomaticaction.org/learn/research.php, accessed 14 May 2008.

Center for Strategic and International Studies. (2007) SCIS Commission on Smart Power: A Smarter, More Secure America . Washington DC: The SCIS Press.

Council on Foreign Relations. (2003) Finding America's Voice: A Strategy for Reinvigorating US Public Diplomacy. Council on Foreign Relations Press, Washington DC, Report of an Independent Task Force.

Cowan, G. and Arsenault, A. (2008) Moving from Monologue to Dialogue to Collaboration: The Three Layers of Public Diplomacy. In: G. Cowan and N.J. Cull (eds.) Public Diplomacy in a Changing World, The Annals of the American Academy of Political and Social Science, Vol. 616 . Philadelphia, PA: Sage, pp. 10-30. 
Cowan, G. and Cull, N. J. (eds.) (2008) Public Diplomacy in a Changing World. The Annals of the American Academy of Political and Social Science, Vol. 616 . Philadelphia, PA: Sage.

Edwards, M. (2000) NGO Rights and Responsibilities: A New Deal for Global Governance . London: Foreign Policy Centre and NCVO.

Fombrun, C. J. (1996) Reputation: Realizing Value from the Corporate Image . Boston, MA: Harvard Business School Press.

Fullerton, J. and Kendrick, A. (2006) Advertising's War on Terrorism: The Story of the US State Department's Shared Values Campaign . Spokane, WA: Marquette Books.

Fullerton, J., Kendrick, A., Chan, K. and Hamilton, M. (2007) Attitudes towards American brands and brand America. Place Branding and Public Diplomacy 3 (3): 205-212.

Gotsi, M. and Wilson, A. M. (2001) Corporate reputation: Seeking a definition. Corporate Communications: An International Journal 6 (1): 24-30.

Grunig, J. E. (1993) Public relations and international affairs: Effects, ethics and responsibility. Journal of International Affairs 47 (1): 137-162.

Grunig, J. E. and Grunig, L. A. (1992) Models of Public Relations and Communication. In: J.E. Grunig (ed.) Excellence in Public Relations and Communication Management . Hillsdale, NJ: Lawrence Erlbaum Associates, pp. 285-325.

Grunig, J. E. and Huang, Y. H. (2000) From Organizational Effectiveness to Relationship Indicators: Antecedents of Relationships, Public Relations Strategies and Relationship Outcomes. In: J.A. Ledingham and S.D. Bruning (eds.) Public Relations as Relationship Management: A Relational Approach to the Study and Practice of Public Relations . Mahwah, NJ: Lawrence Erlbaum Associates, pp. 23-53.

Grunig, J. E. and Repper, F. C. (1992) Strategic Management, Publics, and Issues. In: J.E. Grunig (ed.) Excellence in Public Relations and Communication Management . Hillsdale, NJ: Lawrence Erlbaum Associates, pp. 117-157.

Guilhot, N. (2005) The Democracy Makers: Human Rights and the Politics of Global Order . New York: Columbia University Press.

Hon, L. and Grunig, J. E. (1999) Guidelines for Measuring Relationships in Public Relations . Gainesville, FL: The Institute of Public Relations. 
Hung, C. -J. F. (2007) Toward the Theory of Relationship Management in Public Relations: How to Cultivate Quality Relationships?. In: E. Toth (ed.) The Future of Excellence in Public Relations and Communication Management: Challenges for the Next Generation . Mahwah, NJ: Lawrence Erlbaum Associates, pp. 443476.

Hutton, J. G., Goodman, M. B., Alexander, J. B. and Genest, C. M. (2001) Reputation management: The new face of corporate public relations? Public Relations Review 27 (3): 247-261.

Josselin, D. and Wallace, W. (2001) Non-State Actors in World Politics: The Lessons. In: D. Josselin and W. Wallace (eds.) Non-State Actors in World Politics . London: Palgrave, pp. 251-260.

Kohut, A. and Stokes, B. (2006) America Against the World: How We are Different and Why We are Disliked. New York: Times Books.

Kruckeberg, D. and Vujnovic, M. (2005) Public relations, not propaganda, for US public diplomacy in a post-9/11 world: Challenges and opportunities. Journal of Communication Management 9 (4): 296-304.

Kunczik, M. (1997) Images of Nations and International Public Relations . Mahwah, NJ: Lawrence Erlbaum.

Ledingham, J. A. (2003) Explicating relationship management as a general theory of public relations. Journal of Public Relations Research 15 (2): 181-198.

Ledingham, J. A. and Bruning, S.D. (eds.) (2000) Public Relations as Relationship Management: A Relational Approach to the Study and Practice of Public Relations . Mahwah, NJ: Lawrence Erlbaum Associates.

Lord, C. (2006) Losing Hearts and Minds: Public Diplomacy and Strategic Influence in the Age of Terror. Westport, CT: Praeger Security International.

Malone, G. D. (1988) Political Advocacy and Cultural Communication: Organizing the Nation's Public Diplomacy . Lanham, MD; London: University Press of America.

Manheim, J. B. (1994) Strategic Public Diplomacy and American Foreign Policy: The Evolution of Influence. New York; Oxford, UK: Oxford University Press.

Nye Jr., J. S. (2004) Soft Power: The Means to Succeed in World Politics . New York: Public Affairs.

Osgood, K. (2006) Total Cold War: Eisenhower's Propaganda Battle at Home and Abroad . Lawrence, KS: University Press of Kansas. 
Pigman, G. A. and Deos, A. (2008) Consuls for hire: Private actors, public diplomacy. Place Branding and Public Diplomacy 4 (1): 85-96.

Pilon, J. G. (2007) Why America is Such a Hard Sell: Beyond Pride and Prejudice. New York, NY; Toronto, ON; Plymouth, UK: Rowman \& Littlefield Publishers.

Richmond, Y. (2008) Practicing Public Diplomacy: A Cold War Odyssey . New York; Oxford, UK: Berghahn Books.

Ripinsky, S. and Van den Bossche, P. (2007) NGO Involvement in International Organizations: A Legal Analysis . London: British Institute of International and Comparative Law.

Ross, D. (2007) Statecraft and How to Restore America's Standing in the World . New York: Farrar, Straus and Giroux.

Salamon, L. (1994) The rise of the nonprofit sector. Foreign Affairs 73 : 109-122.

Signitzer, B. and Coombs, T. (1992) Public relations and public diplomacy: Conceptual convergences. Public Relations Review 18 (2): 137-147.

Simmons, P. J. (1998) Learning to live with NGOs. Foreign Policy 112 : 82-96.

Snow Jr., C. (2008) The privatization of US public diplomacy. Fletcher Forum of World Affairs 32 (1): 189-199.

Snow, N. (2003) Information War: American Propaganda, Free Speech and Opinion Control Since 9-11. New York: Seven Stories Press.

Snow, N. (2006) The Arrogance of American Power: What US Leaders are Doing Wrong and Why It's Our Duty to Dissent . New York; Toronto, ON; Plymouth, UK: Rowman \& Littlefield Publishers.

Taylor, P. (1984) Nonstate Actors in International Politics: From Transregional to Substate Organizations . Boulder, CO; London: Westview Press.

Tuch, H. N. (1990) Communicating with the World: US Public Diplomacy Overseas . New York: St Martin's Press, Institute for the Study of Public Diplomacy.

US Department of State. (2007) Private sector summit on public diplomacy: Models for action. A cooperative initiative of US Department of State and the PR Coalition, 9 January, http://www.state.gov/documents/organization/82818.pdf, accessed 29 April 2008. 
US General Accounting Office. (2003) US public diplomacy: State department expands efforts but faces significant challenges. Report to the Committee on International Relations, US House of Representatives, 4 September, http://www.gao.gov/new.items/d03951.pdf, accessed 5 February 2008.

Wang, J. (2006) Managing national reputation and international public relations in the global era: Public diplomacy revisited. Public Relations Review 32 (2): 91-96.

Yang, S. -U. and Grunig, J. E. (2005) The effects of organization-public relationships outcomes on cognitive representations of organizations and overall evaluations of organizational performance. Journal of Communication Management 9 (4): 305-326.

Yun, S. H. (2006) Toward public relations theory-based study of public diplomacy: Testing the applicability of the excellence theory. Journal of Public Relations Research 18 : 287-312.

Yun, S. H. (2008) Cultural consequences on excellence in public diplomacy. Journal of Public Relations Research 20 : 207-230. 